\title{
The Role of Youth in the Development of Cultural Tourism in Tipang Village, Baktiraja District, Humbang Hasundutan Regency
}

\author{
Ayu Anggraini Tambunan', Robert Sibarani², Sakhyan Asmara ${ }^{3}$ \\ 1,2,3 Universitas Sumatera Utara, Indonesia \\ ayutambunan66@gmail.com
}

\begin{abstract}
This research analyzes the role of youth in the development of cultural tourism in Tipang Village, in terms of moral strength, social control, and agents of change, and analyzes the effectiveness of youth activities implementing the 4ASC concept (attraction, accessibility, amenities, ancilliary, safeness, and comfort) in tourism development culture in Tipang Village. Using a qualitative approach with an ethnographic model through in-depth interviews, The results of the study indicate that youth have a role in developing cultural tourism as a moral force; social control; and agents of change; Besides that, youth implement the 4ASC concept (attraction, accessibility, amenity, ancilliary, safeness and comfort) for the development of cultural tourism in Tipang Village, including being involved in developing waterfalls, regional music, king's graves, old villages, souvenirs and traditional rituals (attraction), developing asphalt roads and directions to cultural tourism sites (accessibility). Development of lodging, restaurant, church, poskesdes, electricity and water, as well as providing private vehicle rental (amenities). Development of tourism awareness group organizations (ancilliary). Development of security posts and security guards (safeness). Development of a clean environment and friendly people (comfort). The conclusion of this research is that youth has great potential as the main subject in the development of cultural tourism in Tipang Village. Regional music, king's graves, old villages, souvenirs, and traditional rituals (attraction), development of asphalt roads and directions to cultural tourism sites (accessibility).
\end{abstract}

Keywords

role youth; development; culturetar

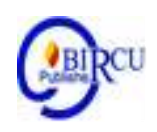

\section{Introduction}

Humbang Hasundutan Regency is one of the districts that has tourist attractions in North Sumatra, be it nature tourism, agro tourism or cultural tourism. In 2017, the performance achievements carried out by the Humbang Hasundutan Regency Tourism Office experienced a significant increase, especially in efforts to develop culture. The cultural diversity management program is divided into five, namely the Lake Toba festival, the opening of the PRSU, consolidating the management of sites, culture and tourism destinations, focus group discussion (attractions, cultural performances) typical of Humbang Hasundutan Regency, as well as the Gondang Sabangunan festival.

There are still many tourism sector in Humbang Hasundutan Regency that are still unknown to the outside community, especially in Tipang Village which is one of 7 (seven) villages in Baktiraja District. Of these 7 (seven) villages, Tipang Village is one of 4 (four) villages that are in direct contact with Lake Toba. Tipang Village was inaugurated as a cultural 
tourism village in 2018 by the Regent Humbang Hasundutan. There are academics from tertiary institutions who make Tipang Village a fostered object aimed at advancing the village and the welfare of the village community.

In developing cultural tourism objects in Tipang Village, it is necessary to pay attention to the 4ASC concept, namely attraction, accessibility, amenities, ancillary, safeness, and comfort, the goal is to make tourists more interested and more comfortable in Tipang Village. (Sibarani 2017: 1).

The development of cultural tourism certainly requires increasing the utilization of youth potential optimally. In order to realize an order for implementing village development that is in accordance with current aspirations and demands, it requires local government policies and management that are effective, efficient and able to move all the resources owned by the village towards being sustainable for the welfare of its citizens, including one of them by mobilizing village youth resources. . This is indicated by the presence and activity of the Pokdarwis (Tourism Awareness Group) organization in Tipang Village. The big role played by the youth of Tipang Village in developing the village into a culture-based tourism village is the basic reason for conducting an in-depth study of "The Role of Youth in the Development of Cultural Tourism in Tipang Village".

\section{Review of Literatures}

Regional development is an effort in an administrative area or a certain area in order to achieve prosperity through optimal, efficient, synergic and sustainable exploitation of resources by means of stimulating economic activities, creating a conducive climate, protecting the environment and providing infrastructure and facilities. . Basically, the main component for achieving the welfare of the people in an area is the economic progress of the region concerned.

Tourism is an industrial sector which is currently got a lot of attention from many countries in the world. The tourism sector is believed to have the ability to increase economic growth (Maciej Debski 2013). Moreover, the tourism sector is positively encouraged to be able to replace the oil and gas sector which has been the main capital in the country's foreign exchange earnings (Siswanto 2007). The advantage of the tourism sector lies in its ability to increase foreign exchange and to drive various other business sectors such as the home industry. Thus, developed countries and developing countries continue to develop and improve the quality of their country's tourism. (Amin et al, 2019)

Tourism is one of the determinants of national economic growth because it can influence the growth of other sectors in the economy (Gokovali \& Bahar, 2006) and also grows very fast during this decade (Dogru \& Bulut, 2018; Wu et al., 2000). Sustainable tourism development can be completed by creating opportunities through networking and cooperation with service providers, where stakeholder engagement, the development of locally oriented codes of conduct, and local government participation are crucial factors for sustainable tourism success (Welford \& Ytterhus in Nurlina, 2020).

Cultural tourism is a type of tourism which in its development and development uses culture as a dominant basic potential, which implies an ideal of a dynamic and positive reciprocal relationship between tourism and culture, so that both increase harmoniously, harmoniously and in balance. Therefore, tourism development is expected to always pay attention to the preservation of the nation's arts and culture which is used as an asset for Indonesian tourism. 
The definition of youth in Law Number 40 of 2009 concerning Youth regulates the roles, responsibilities and rights of youth. This is stated in Article 16 "Youth plays an active role as a moral force, social control, and agents of change in all aspects of national development". Continued in Article 1 paragraph (1), defines that "Youth are Indonesian citizens who enter an important period of growth and development aged 16 (sixteen) to 30 (thirty) years". From this law it is clear that youth is viewed from three perspectives, namely as a moral force, social control, and agents of change in developing or developing regions.

\section{Research Methods}

This study uses a qualitative approach with an ethnographic model through in-depth interviews, field observations, and documentation as research support, coupled with virtual interviews and virtual observations due to the spread of the COVID-19 virus.

\section{Results and Discussion}

\subsection{The Role of Youth as Moral Force, Social Control, and Agent of Change in the Development of Cultural Tourism Objects}

The results of research on the role of youth as a moral force, social control, and agents of change in the development of cultural tourism can be seen in the following description:

\section{a. Moral Power}

1. Youths respect each other for different beliefs with tourists.

2. Youths establish friendship with tourists.

3. Youth ethics in accompanying tourists prioritize the wishes of tourists.

4. Youth character is built together in accordance with the village government program that wants to create friendly youth, so as to make tourists feel comfortable by traveling to Tipang Village.

5. Tipang Village youths have high tolerance. Never use the local language in front of tourists who do not understand the language.

6. Youths use calls to older tourists with traditional Batak Toba speech. This shows that youth have good ethics by upholding cultural values.

\section{b. Social Control}

1. Youth always pay attention to the development of village tourism areas and supervise any tourism development in Tipang Village.

2. Youth play an active role as a media that disseminates information to the public and tourists regarding information about tourism development and development in Tipang Village.

3. Youth as the activator to clean up the village area by working together.

4. Youths invite the public and tourists to maintain the cleanliness of cultural tourism areas, by not littering.

5. Youth plays a role in communicating the needs of tourists to the village government.

6. Youth strive for the development of cultural tourism in accordance with tourist expectations. Both in terms of access to tourist sites, as well as security while traveling to tourist destinations.

7. Youth as representatives of Tipang Village in activities facilitated by the Humbang Hasundutan Regency Tourism Office. 
c. Agent of Change

1. Youths hold the association of the Tourism Awareness Group (Pokdarwis) every week to improve tourism science.

2. Youth use agricultural products to process them into typical culinary delights of Tipang Village.

3. The youth invites all people to keep the waterfall to remain as irrigation for Tipang Village, and for attractions that tourists can enjoy its beauty.

4. Tipang Village youth learn about strategies for the use, development and management of tourism areas through activities facilitated by the government.

5. Youth make access to the hill so they can enjoy the beauty of Tipang Village from a height.

6. The youth asked all tourists not to hesitate to inform them about their discomfort while in Tipang Village.

7. Youths are always enthusiastic about supporting the development of cultural tourism objects in the continuity of tourism activities.

4.2 Implementing the 4ASC Concept (Attraction, Accessibility, Amenity, Ancilliary, Safeness, and Comfort) in the Development of Cultural Tourism

a. Attraction

\section{Sigota-gota Sipultak Hoda Waterfall}

Sigota-gota Sipultak Hoda Waterfall is one of the historical sites left by King Sisingamangaraja. This waterfall is the irrigation of Tipang Village which flows directly into Lake Toba. In the past, this waterfall was used by the community as a place to meditate to purify themselves. This waterfall can generate community entrepreneurship if it is used as a camping ground area, trekking and as a fishing location by making certain rates. But unfortunately the youth still haven't used it. Even if this is done, then there will be economic benefits such as the existence of Regional Original Income, job opportunities to open businesses around the waterfall location, open employment opportunities for village youth, increase village community income and encourage village development.

\section{Folk Music}

There are Tipang Village youths who often play Batak Toba music with special wooden musical instruments consisting of taganing, flute, hasafi, hesek, saruna etek and garoptu, consisting of 12 (twelve) musicians and 12 (twelve) people as musicians. dancer. Tipang Village youths are not very active in playing this instrument. Youth only play this instrument as part of their hobby. In fact, if it is played routinely like in Batak cultural tourism objects in general, it will give rise to socio-cultural benefits in the development of cultural tourism, such as preserving culture and customs. Because in general, cultural tourism objects are identical to local music. Such as at the village entrance, restaurant, and certain points that have been determined by the community. However, this still cannot be realized because Tipang Village is a cultural tourism village that was recently inaugurated by the government. So that there are still many people who do not know Tipang Village and tourists who visit Tipang Village are still very rare. The community and government of Tipang Village are still trying to introduce their village which is still unknown to many people.

Apart from the socio-cultural benefits, promoting local music will also have economic benefits. Because it is not uncommon for tourists who enjoy regional musical attractions to provide saweran or voluntary donations to musicians or dancers through durung-durung or the containers that have been provided. Usually the saweran results will be used to develop the music community. 


\section{Batu Siungkap-Ungkapon}

The Batu Siungkap-ungkapon is one of the historical relics which in ancient times was used as a reference for reaping rice seeds. This stone is in the Sosor Julu village. According to the story, if it was opened during the rice planting period by the people of Tipang Village, if there were white ant eggs from the stone, then it was an indication that the community would plant white rice seeds. On the other hand, if there are red ant eggs, the community must plant red rice seeds. So the Batu siungkapungkaponis a means of asking ancestors for directions in relation to agriculture (Wiradnyana \& Lucas, 2014: 12).

The reason for the Batu siungkapungkaponbeing in Tipang Village is because the people of Tipang Village who started to strengthen the Batak custom were initially mardingdinghon dolok, namaralamanhon tao, namartaruphon ombun (hillside, lake yard, cloud roof). However, now these Si disclosed stones are no longer used by the people of Tipang Village to reap rice seeds. This stone is only used as a historical relic and is used as a cultural tourism object in Tipang Village. The last time the researchers carried out research into the Si disclosed rock area, this historic stone condition was surrounded by 30 centimeter high weeds. It seems that the youth of Tipang Village paid little attention to the state of this historic stone. Even if it is treated maximally, This Batu siungkapungkaponhas an attraction to be visited by archaeologists or cultural observers. Researchers did not get information regarding the age of the Si disclosed stone, because the informant did not know the exact age of the stone.

\section{Rumah Bolon}

Usually the Rumah bolon which is used as a cultural tourism object is painted in accordance with the carved ornaments. However, for the Rumah bolonin Huta Banjar Ganjang the color is natural wood, it looks like the paint on the Rumah bolonbuilding has faded. This Rumah bolonis still used as a residence by their descendants. With the permission of the owner, the young man of Tipang Village introduced this Rumah bolon to visiting tourists, even tourists were allowed to enter to see the situation inside.

After the researchers observed the location of the bolon house, the community still had not made the Rumah bolona special tourist attraction. The government also cannot make the Rumah bolona special tourist attraction that is freely owned by the village. Because the Rumah bolonis a private house passed down from generation to generation by King Ijulu Manalu. And also to enter the Rumah bolonis still not paid or free. So that Tipang Village still cannot take advantage of the economic opportunities in the Rumah bolonenvironment. Even though if the people's income increases through tourists, it will have an impact on Tipang Village, especially on the tourist attraction of the Rumah bolonitself. And the cost of these rates can be used as bolon home care with the aim of increasing the attractiveness of tourists to tourist objects.

\section{Sarkopagus Raja Ijulu Manalu (Batu Lubang Banjar Ganjang)}

Now, many tourists visit the Sarkopagus Raja Ijulu Manalu (Batu Lubang Banjar Ganjang) to find out about cultural history in ancient times. Tipang Village youths use this hole stone as a tourist attraction and promote it on their personal social media accounts. Youths also participate in cleaning the hole stones so that tourists can enjoy the attraction of the stone holes that are 220 years old.

Just like the bolon house, to enter the stone hole tourist attraction area, it still doesn't have a tariff. So that people still do not get economic benefits from the existence of this Banjar Ganjang stone tourist attraction. The community, especially youth, only take advantage of this tourist attraction as a socio-cultural benefit, such as preserving culture and customs. This is because there are still not many tourists visiting Tipang Village so that Tipang Village still cannot take advantage of the economic opportunities in the tourist attraction environment. 


\section{Borsak Mangatasi Nababan}

On October 13, tourists with the clan of Nababan will visit Tipang Village as a partangiangan day (day of prayer). As for the purpose and purpose of the celebration held annually by tourists not just gathering, but praying together for the ancestors and grandchildren of the Nababan clan.

As for what youths can do at the Borsak Mangatasi Nababan tourist attraction, who is 325 years old, is just to participate in maintaining the cleanliness of the tomb and the cleanliness of the road to Borsak Mangatasi Nababan. Youth take advantage of the development of cultural tourism objects in terms of socio-culture and environment. Such as preserving culture and customs and maintaining a clean environment of tourist attractions in Nababan and away from the population.

\section{Somba Debata Sarcophagus}

In Tipang Village, there is the tomb of King Ompu Purba, precisely in the Huta Bagasan village. Somba Debata sarcophagus is a grave or meal for Ompu Somba Debata Raja, the 2nd generation heir of the Purba clan and is currently 220 years old. Just like Borsak Mangatasi Nababan, Sarkopagus Dihorbo Purba is also frequently visited by tourists from the Purba clan to pray to ancestors and descendants of the Purba clan.

As for what youths can do at the Dihorbo Purba sarcophagus attraction, is to participate in maintaining the cleanliness of the tomb and the cleanliness of the road to the Dihorbo Purba sarcophagus. Youth take advantage of the development of cultural tourism objects in terms of socio-culture and environment. Such as preserving culture and customs and keeping the environment of the sarcophagus tourist attraction clean and away from the population.

\section{Borsak Simuranggur Sihombing Lumbantoruan Monument}

Most of the tourists who visit Tipang Village, apart from enjoying the beautiful natural scenery, also don't forget to visit the Borsak Simuranggur Sihombing Lumbantoruan monument or what is usually referred to as the Sihombing monument. In 2012 the youth of Tipang Village participated in the construction of this monument. And now what Tipang Village youths are doing is utilizing technology to introduce the Bona Pasogit Borsak Sirumonggur Monument (Sihombing Monument). Youth also participated in cleaning up the monument area.

\section{b. Accessibility}

Access in the form of a road to Tipang Village is currently very good. Judging from the road infrastructure, the road access in Tipang Village is not damaged but the width of the road is still small. So that tourists who bring buses will find it difficult to enter Tipang Village. For air routes, the closest airport to Tipang Village is Silangit Airport which is in Siborong-Borong, North Tapanuli Regency with a distance of $41 \mathrm{Km}$ and a distance of 1 hour 5 minutes (land) via Kota Dolok Sanggul (the capital of Humbang Hasundutan Regency).

The trip from the provincial capital (Medan City) to Tipang Village takes 7 (seven) hours of travel. When the researcher arrived at Tipang Village for the first time, the researcher felt that the road conditions to Tipang Village were very good. The asphalt road with beautiful views along the way plus the existence of public transportation (mini bus) from the provincial capital (Medan City) to Tipang Village, makes anyone who comes must not think about being afraid of getting lost because they don't have to move buses. The telephone and internet networks are also smooth. This may imply that the telecommunications company also acknowledges that network usage in Tipang Village is up to standard. 
When the researcher visited the Sigota-gota Sipultak Hoda waterfall, the researcher observed that the road conditions were also clean, and access to the waterfall was already there. Tipang Village youths do mutual cooperation to clean up access to the waterfall tourist location. Not only cleaning, the youth of Tipang Village are also happy to escort the tourists to the location of the waterfall. Besides the waterfall, access to the old village is also good. However, the journey to Mual Purba is still not fully asphalt. About 100 meters of road conditions are still dirt and will be muddy when it rains. Youths have also made directions to tourist objects, this is done so that tourists have no trouble finding the location of certain tourist objects.

\section{c. Amenity}

Amenity is accommodation that includes facilities and infrastructure. The accommodation is a commercially constructed building. The accommodation in Tipang Village is 4 (four) inns, namely BUMDes homestay, Parmuse Homestay, Batugaja, and Tipang Mas. Among the four inns, there are two restaurants, namely Batugaja restaurant and Tipang Mas restaurant. Apart from lodging and restaurants, public facilities in Tipang Village include the HKBP church's house of worship, the village health post, electricity and clean water flowing from the mountains. Tipang Village youths also take advantage of the opportunity to rent vehicles in Tipang Village because Tipang Village does not yet have special transportation to go to cultural tourism locations. However, the youth of Tipang Village have never asked for special rates, but rather sincerity from tourists.

Aspects of amenities in Tipang Village still need to be developed again such as the availability of a tourism information center, ATMs, and if necessary a money changer, considering that the tourist location of Tipang Village is very close to Samosir Island which is visited by many foreign tourists. The tourism information center is only in the form of posts on personal social media or regional news managed by the Humbang Hasundutan Regency Culture and Tourism Office to promote all tourist attractions. Other things that need to be built are a souvenir shop, public toilets and prayer rooms.

\section{d. Ancilliary}

Ancilliaryare things that support a tourism, such as management institutions that play a role in tourism. In Tipang Village, there is a Tourism Awareness Group (Pokdarwis) organization that develops cultural tourism objects. Tipang Village youths are active in tourism activities organized by the government. Through this tourism awareness group, it is hoped that the youth can be fostered and can make cultural tourism objects in Tipang Village known to the wider community.

Representatives from the Tourism Awareness Group representing Tipang Village were once invited to attend training on tourism in Yogyakarta. Then in November 2019, the youth of Tipang Village were invited to a workshop by the Humbang Hasundutan Regency Tourism Office to study tourism at Tano Tubu Doloksanggul. This activity aims to improve knowledge about tourism in Tipang Village. Through a workshop entitled "Generation Positive Thinking (Genposting)", it is hoped that young people can understand how to carry out tourism promotion, promotion through interactive social media in an effort to improve the tourism industry in Indonesia.

\section{e. Safeness}

In Tipang Village, there is no special announcement that the safety of tourists is guaranteed by the people of Tipang Village, it's just that if things happen that are not desirable such as an accident during a tour, then the youth of Tipang Village are ready to help tourists. In addition to accidents, the Head of Tipang Village has also appealed to the community, 
especially the youth, to maintain security at the tourist site of Tipang Village from physical or other crimes. With the existence of a security post in Tipang Village, it is hoped that the youth will be active in carrying out security activities so that crime and criminality will not occur in any form.

However, it is very unfortunate that there are community pets still roaming the village, namely dogs. There is no special appeal to the public to secure or house these pets. The people of Tipang Village feel that these pets are safe and tame, so they will not harm visiting tourists. This will make tourists feel afraid if they are bitten and have fatal consequences for tourists or the Tipang Village itself.

Where in regional development theory refers to social development, one of which is environmental quality. A clean and safe environment is one of the main destinations for tourists to be attracted by these tourist locations. However, researchers still have not found the level of safety of the pets roaming the village of Tipang, because these animals are not tied up and are not vaccinated. So that unwanted things could happen to tourists.

\section{f. Comfort}

Tipang Village youths are always friendly to anyone who travels to Tipang Village. Always greeting tourists who pass by, coupled with the comfort found in Tipang Village with regard to mental tranquility due to cool temperatures, environmental cleanliness, order and beauty of both the environment, culture and nature. Tipang Village is one of the cleanest tourist areas around Lake Toba. This was crowned by the Ministry of Tourism of the Republic of Indonesia and received a fund of Rp. 40,000,000.00 (forty million rupiah) for the achievement.

The Head of Tipang Village has urged the community to cooperate with each other in making Tipang Village clean, this appeal has also been written and posted at several points in Tipang Village. The goal is to make people remember by reading the writing. The contents of the text are "poda na lima, first paias roham, second paias pamatangmu, three pahiasmu paheanmu, four pahiasmu bagasmu, and the fifth pahias pahiasmu".

\section{Conclusion}

After the researcher conducts research on the title as material for writing this thesis, the researcher can draw the following conclusions:

1. Three roles of youth in the development of cultural tourism objects in Tipang Village, including (1) the role of youth as a moral force, manifested by developing aspects of ethics and morality, strengthening faith and piety as well as mental-spiritual endurance and increasing legal awareness. (2) The role of youth as social control is manifested by raising awareness of responsibilities, rights and obligations as well as generating a critical attitude towards the environment. (3) The role of youth as agents of change is manifested by concern for society and the environment, science and technology, and entrepreneurship education.

2. Youth implement the concept of tourism development through 4ASC (attraction, accessibility, amenity, ancillary, safeness, and comfort), namely by developing existing attractions such as natural destinations and historical heritage sites, but until now there is no set fee for entering the site. cultural tourism object. Developing accessibility, namely by building access to cultural tourism objects. Developing amenities, namely by helping to build and maintain tourism facilities. Develop ancilliary, namely by increasing the science of tourism through the Tourism Awareness Group. Developing safeness, namely by maintaining village security and order. As well as developing Comfort, namely by making the environment comfortable and clean, and having a friendly attitude. 


\section{References}

Amin, M et al. (2019). Marketing Communication Strategy To Improve Tourism Potential. Budapest International Research and Critics Institute-Journal (BIRCI-Journal). P. 160166.

Anisa, Nur Widyastuti.(2014). Community Based Village Tourism Management in Kebonagung Village, Bantul Regency.Journal.

Creswell, John W. (2009). Research Design: Qualitative, and Quantitative Approaches Mix. Yogyakarta: Student Library.

Lexy, J. Moleong. (2006). Qualitative Research Methodology. Bandung: PT Youth Rosdakarya.

Nurlina, (2020). Tourism Development in Langsa, Indonesia: An Overview of Tourist Attractions and Accommodation. Budapest International Research and Critics InstituteJournal (BIRCI-Journal). P.923-931

Pendit, Nyoman S. (1990). Tourism Science: A First Introduction. Jakarta: Pradnya Paramita. Pitama, I Gde, et al. (2009). Introduction to Tourism Science. Yogyakarta: Andi.

Sibarani, Robert. (2014). The Nature of Local Wisdom, Role, and Tradition Methods Oral. Jakarta: Association of Oral Traditions.

Spradley, James. (1997). Participant Observation.

Sujali. 1989. Geography of Tourism and Tourism. Faculty of Geography UGM. Yogyakarta Law Number 40 of 2009 concerning Youth.

Wow, wrong. (1992). Tourism Management. Jakarta: Pradnya Paramita.

Yunita, Oka A. (1985). Tourism Marketing. Bandung; Space. 